\title{
Umocowanie wspólnika do reprezentowania spółki jawnej a prawo i obowiązek prowadzenia jej spraw
}

\author{
Authority of a partner to represent a general partnership and the right and duty \\ to manage its affairs
}

\author{
Полномочие участника представлять полное товарищество, \\ а право и обязанность вести его дела \\ DARIUSZ BUCIOR \\ Dr, Katolicki Uniwersytet Lubelski Jana Pawła II \\ e-mail: dariusz.bucior@kul.pl, http://orcid.org/0000-0002-5474-836X
}

\begin{abstract}
Streszczenie: Artykuł dotyczy relacji między „prawem reprezentowania spółki” (art. 29 § 1 Kodeksu spółek handlowych) a "prawem i obowiązkiem prowadzenia spraw spółki” (art. 39 § 1 Kodeksu spółek handlowych). Terminy te opisują status wspólników jako zarządców spółki. W pierwszym kroku przedstawiono stanowisko literatury niemieckiej w odniesieniu do takich samych zwrotów użytych w niemieckim kodeksie handlowym; stanowisko nawiązujące do XIX-wiecznej koncepcji Paula Labanda rozróżnienia umocowania oraz zlecenia. Następnie poddano krytycznej analizie prezentowane w polskiej literaturze poglądy na temat relacji między „prowadzeniem spraw spółki” a "reprezentacją." W artykule broniona jest teza, że "prawo reprezentowania spółki” oznacza umocowanie do reprezentowania, zaś przepisy o prowadzeniu spraw spółki stanowią źródło stosunku podstawowego (wewnętrznego) dla umocowania do reprezentowania.
\end{abstract}

Słowa kluczowe: spółka jawna, prowadzenie spraw, reprezentacja

Summary: The article concerns the relation between the "right to represent the partnership" (Article $29 \S 1$ of the Commercial Companies Code) and the "right and duty to manage the affairs of the partnership" (Article 39 $\S 1$ of the Commercial Companies Code). These terms describe the status of partners as managers of the partnership. First, the position of German literature is presented in relation to the same phrases used in the German Commercial Code; the position originating in the 19th-century concept of Paul Laband's distinction between authority and mandate. A critical analysis is then made of the views presented in the Polish literature on the relationship between "managing the affairs of the partnership" and "representation". The paper defends the thesis that the "right to represent the partnership" means having the authority to represent, and the provisions regarding managing the affairs of the partnership constitute the basic (internal) relationship for the authority to represent.

Key words: general partnership, managing of affairs, representation

Резюме: В статье рассматривается взаимосвязь между «правом представлять товарищество» (статья 29 $\S 1$ Кодекса хозяйственных товариществ и обществ) и «право и обязанность вести дела товарищества» (Статья 39 § 1 Кодекса хозяйственных товариществ и обществ). Эти термины описывают статус участников как управляющих делами товарищества. На первом этапе представлена позиция немецкой литературы по отношению к тем же фразам, используемым в Торговом кодексе Германии; позиция, отсылающая к концепции из XIX века Пауля Лабанда о различии между полномочиями и поручением. Далее проводится критический анализ представленных в польской литературе взглядов на соотношение между «ведением дел товарищества» и «представительством». В статье отстаивается тезис о том, что «право представлять товарищество» означает полномочие представительства, а положения о ведении дел товарищества являются источником базовых (внутренних) отношений для полномочия представительства.

Ключевые слова: полное товарищество, ведением дел, представительство 


\section{Wstęp}

Spółka jawna jako podmiot (art. $8 \$ 1$ ustawy z dnia 15 września 2000 r. - Kodeks spółek handlowych ${ }^{1}$ ) działa przez swoich wspólników. Opisując ich status w tym zakresie, ustawodawca używa terminów „prowadzenie spraw spółki” oraz „reprezentowanie spółki”. Z przepisów rozdziału 3 działu I tytułu II K.s.h., zatytułowanego „Stosunki wewnętrzne spółki”, wynika, że wspólnik ma prawo i obowiązek prowadzenia spraw spółki (art. $39 \$ 1$ K.s.h.), przy czym sprawy nieprzekraczające zakresu zwykłych czynności spółki mogą być prowadzone przez wspólnika bez uchwały wspólników (art. $39 \$ 2$ K.s.h.), natomiast sprawy przekraczające ten zakres wymagają zgody wszystkich wspólników (art. 43 K.s.h.). Z kolei przepisy rozdziału 2 („Stosunek do osób trzecich”) wyrażają zasadę, że wspólnik ma prawo reprezentować spółkę (art. $29 \$ 1$ K.s.h.) w zakresie wszystkich czynności sądowych i pozasądowych spółki (art. $29 \$ 2$ K.s.h.), przy czym prawa tego nie można ograniczyć ze skutkiem wobec osób trzecich (art. $29 \$ 2$ K.s.h.).

Celem artykułu jest wyjaśnienie relacji między „prawem reprezentowania spółki” a „prawem i obowiązkiem prowadzenia spraw spółki”. Z uwagi na to, że regulacja K.s.h. dotycząca spółki jawnej ma genezę w regulacji prawa niemieckiego ${ }^{2}$, analiza polskich przepisów poprzedzona zostanie przedstawieniem uwag dotyczących prawa niemieckiego.

\section{Uwagi dotyczące prawa niemieckiego}

W prawie niemieckim spółka jawna regulowana jest przez przepisy $₫ 105-160$ kodeksu handlowego z dnia 10 maja 1897 r. (Handelsgesetzbuch) ${ }^{3}$, stanowiące rozdział pierwszy księgi drugiej HGB. Przepisy dotyczące prowadzenia spraw pomieszczone są w tytule drugim zatytułowanym „Stosunek prawny między wspólnikami”, zaś przepisy o reprezentacji w tytule trzecim - „Stosunek wspólników do osób trzecich”.

Zgodnie $\mathrm{z} \$ 114$ ust. 1 HGB wspólnicy są uprawnieni i zobowiązani do prowadzenia spraw spółki w zakresie wszystkich czynności, które są związane z normalnym prowadzeniem przedsiębiorstwa handlowego spółki. Czynności, które wykraczają

1 Tekst jednolity: Dz. U. z 2020 r. poz. 1526 z późn. zm. (dalej: K.s.h.).

2 Przepisy K.s.h. o spółce jawnej bazują na regulacji Kodeksu handlowego, która w dużej części stanowiła kopię regulacji niemieckiej.

3 Dalej: HGB. Aktualny tekst jednolity dostępny na stronie niemieckiego Ministerstwa Sprawiedliwości i Ochrony Konsumentów: https://www.gesetze-im-internet.de/hgb/ [dostęp: 22.06.2021 r.]. 
poza ten zakres, wymagają uchwały wszystkich wspólników ( $\$ 116$ ust. 2 HGB). Autonomiczne zasady przewidziano w odniesieniu do powołania i odwołania prokurenta (\$ 116 ust. 3 HGB).

W odniesieniu do reprezentacji ogólną zasadę formułuje $\$ 125$ ust. 1 HGB, zgodnie z którym do reprezentowania spółki umocowany (ermächtigt) jest każdy wspólnik (samodzielnie - zob. $\$ 125$ ust. 2 i 3 HGB), jeżeli w umowie spółki nie został wyłączony od reprezentowania. Umocowanie obejmuje wszystkie sprawy i działania prawne, sądowe i pozasądowe, w tym zbywanie i obciążanie nieruchomości oraz udzielanie i odwoływanie prokury ( $\$ 126$ ust. 1 HGB).

W literaturze wskazuje się, że w zakresie prowadzenia spraw spółki i reprezentacji regulacja HGB systemowo nawiązuje do wynikającego z niemieckiego kodeksu cywilnego z dnia 18 sierpnia 1896 r. (Bürgerliches Gesetzbuch) ${ }^{4}$ rozróżnienia między zleceniem a pełnomocnictwem ( $\$ 662$ oraz $\$ 167$ BGB), mającego swój początek w XIX-wiecznej koncepcji Paula Labanda ${ }^{5}$, przedstawionej w rozprawie pt. Die Stellvertretung bei dem Abschluß von Rechtsgeschäften nach dem allgem. Deutsch. Handelsgesetzbuch ${ }^{6}$. Ocenia się, że rozprawa ta stanowiła impuls do rozwoju nowoczesnej nauki o pełnomocnictwie ${ }^{7}$, w istocie jednak jej znaczenie nie ogranicza się tylko do pełnomocnictwa jako umocowania wynikającego z woli stron, ale dotyczy przedstawicielstwa (Stellvertretung) jako takiego.

Głównym założeniem koncepcji P. Labanda było odgraniczenie umocowania ${ }^{8}$ od zlecenia. Zdaniem autora brak jest koniecznego związku między umocowaniem a zleceniem, w szczególności nie stanowią one wewnętrznej i zewnętrznej strony tego samego stosunku prawnego, lecz są dwoma różnymi stosunkami. Może bowiem istnieć zlecenie bez umocowania, jak i umocowanie bez zlecenia9. W ocenie P. Labanda umocowanie daje możliwość, aby przez zawierane przez siebie - lecz w cudzym imieniu - umowy, nabywać prawa dla innej osoby lub

4 Dalej: BGB. Aktualny tekst jednolity dostępny na stronie niemieckiego Ministerstwa Sprawiedliwości i Ochrony Konsumentów: https://www.gesetze-im-internet.de/bgb/ [dostęp: 22.06 .2021 r.].

5 C. Schäfer, w: M. Habersack, C. Schäfer, Das Recht der OHG. Kommentierung der \$\$ 105 bis 160 HGB, Berlin-New York 2010, \$114, Nb. 13.

$6 \quad$ P. Laband, Die Stellvertretung bei dem Abschluß von Rechtsgeschäften nach dem allgem. Deutsch. Handelsgesetzbuch, Zeitschrift für das gesamte Handelsrecht 1866, t. 10.

7 Tak znaczenie tej pracy ocenia E. Gerke, Vertretungsmacht und Vertretungsberechtigung. Eine civilistische Untersuchung, Köln-Berlin-Bonn-München 1981, s. 1. Koncepcja P. Labanda określana jest jako „prawnicze odkrycie” czy „wspaniałe osiągnięcie” myśli prawniczej, zob. W. Flume, Allgemeiner Teil des Bürgerlichen Rechts, t. 2, wyd. 2, Berlin-Heidelberg-New York 1975, s. 787.

8 Autor używał terminu Vollmacht (współcześnie rozumianego jako pełnomocnictwo), przy czym w szerokim znaczeniu, obejmującym m.in. prokurę, umocowanie wspólnika jawnego czy umocowanie członka zarządu spółki akcyjnej, zob. P. Laband, Die Stellvertretung..., s. 205.

9 Tamże, s. 203-205. 
zobowiązywać inną osobę, niezależnie od tego, czy inna osoba zawarcie danej umowy nakazała albo czy pozostawiła umocowanemu decyzję w tym zakresie, czy też może wręcz zakazała zawarcia umowy. Tym samym zlecenie jest irrelewantne dla umocowania ${ }^{10}$.

Niezależność umocowania i zlecenia P. Laband uzasadniał m.in. przykładem prokury i reprezentacji spółki jawnej przez wspólnika, przy czym uwagi formułował $\mathrm{w}$ odniesieniu do regulacji powszechnego niemieckiego kodeksu handlowego z 1861 r. (Allgemeines Deutsches Handelsgesetzbuch). Zdaniem autora prokurent i wspólnik jawny posiadają umocowanie do reprezentowania, niezależnie od tego, czy posiadają zlecenie. Jeżeli mocodawca zabronił prokurentowi dokonywania określonych czynności, to czynność dokonana przez prokurenta wbrew zakazowi będzie zobowiązywać mocodawcę. Podobnie, jeżeli wspólnik jawny zawarł z osobą trzecią umowę wbrew uchwale wspólników - czynność będzie wiązać spółkę. Czynności takie mogą narazić prokurenta czy wspólnika jawnego na odpowiedzialność wobec mocodawcy (w przypadku prokurenta) czy wobec pozostałych wspólników (w przypadku wspólnika jawnego); są jednak skuteczne ${ }^{11}$. Odwoływanie się do zlecenia przy ocenie sytuacji wspólnika jawnego potwierdza spostrzeżenie dokonane przez E. Gerke, że P. Laband przez zlecenie rozumiał każdy stosunek zobowiązaniowy wynikający z czynności prawnej, dotyczący udzielenia i korzystania $\mathrm{z}$ umocowania ${ }^{12}$.

Dokonane przez P. Labanda pojęciowe odgraniczenie umocowania od zlecenia stanowi podstawę powszechnego we współczesnej niemieckiej nauce o przedstawicielstwie rozróżnienia na umocowanie do reprezentowania oraz stosunek wewnętrzny. Umocowanie do reprezentowania (niem. Vertretungsmacht) jest terminem ustawowym, używanym w przepisach BGB o reprezentacji i pełnomocnictwie ( $\$ 164$ i nast. BGB). Przez umocowanie do reprezentowania rozumie się moc prawną (niem. Rechtsmacht), dzięki której przedstawiciel jest w stanie dokonywać czynności prawnych ze skutkami dla reprezentowanego (używa się również określeń: legitymacja, kompetencja ${ }^{13}$. Jest to pojęcie będące elementem stosunku zewnętrznego. Służy ono wyłącznie rozstrzygnięciu, czy czynność dokonana przez przedstawiciela wiąże reprezentowanego w relacji do osoby trzeciej będącej drugą stroną czynności. Jeżeli zatem stwierdza się, że pojęcie umocowania do reprezentowania

\footnotetext{
10 Tamże, s. 206.

11 Tamże, s. 205 i 206.

12 E. Gerke, Vertretungsmacht..., s. 1.

13 K. Larenz, M. Wolf, Allgemeiner Teil des Bürgerlichen Rechts, wyd. 8, München 1997, s. 861, 874; C. Schubert, w: Münchener Kommentar zum Bürgerlichen Gesetzbuch, t. 1, red. C. Schubert, wyd. 8, München 2018, § 164, Nb. 182; W. Flume, Allgemeiner..., s. 780.
} 
opisuje to, co przedstawiciel może zrobić w stosunku zewnętrznym ${ }^{14}$, oznacza to jedynie, że jeżeli przedstawiciel dokona czynności objętej umocowaniem, czynność ta będzie wiązać reprezentowanego ${ }^{15}$. Posiadanie umocowania do reprezentowania nie rozstrzyga natomiast o tym, czy przedstawiciel jest uprawniony - w stosunku do reprezentowanego - do dokonania danej czynności. O tym, czy przedstawicielowi przysługuje skuteczne wobec reprezentowanego uprawnienie do reprezentowania (niem. Vertretungsberechtigung) ${ }^{16}$, decyduje stosunek wewnętrzny (podstawowy) łączący przedstawiciela $z$ reprezentowanym. Przez stosunek wewnętrzny rozumie się wynikający z czynności prawnej stosunek zobowiązaniowy, który reguluje sposób wykonywania umocowania do reprezentowania ${ }^{17}$, czyli to, czy i w jaki sposób przedstawiciel może i powinien wykonywać umocowanie ${ }^{18}$. Relację między umocowaniem do reprezentowania a stosunkiem wewnętrznym dobrze oddaje spotykane sformułowanie, że umocowanie do reprezentowania stanowi Können (czyli faktyczną możliwość dokonania czynności ze skutkiem dla reprezentowanego), zaś stosunek wewnętrzny: Dürfen (czyli stosunek wewnętrzny określa, czy w stosunku do reprezentowanego przedstawiciel jest uprawniony do skorzystania $z$ umocowania $)^{19}$. W przypadku gdy przedstawiciel dokona czynności prawnej mieszczącej się w zakresie umocowania, lecz do dokonania której w ramach stosunku wewnętrznego nie był uprawniony, czynność prawna jest ważna i wiąże reprezentowanego, z zastrzeżeniem wyjątków kwalifikowanych jako nadużycie umocowania ${ }^{20}$.

Rozróżnienie na umocowanie do reprezentowania oraz stosunek wewnętrzny wykorzystywane jest w literaturze niemieckiej do objaśniania przepisów o prowadzeniu spraw i reprezentacji spółki jawnej. Prowadzenie spraw spółki rozumiane jest szeroko, jako każdego rodzaju działalność ukierunkowana na osiągnięcie celu spółki ${ }^{21}$, czy też jako każda świadoma i celowa działalność w sferze prawnej lub

14 K. Larenz, M. Wolf, Allgemeiner..., s. 894.

15 W. Flume, Allgemeiner..., s. 787; E. Gerke, Vertretungsmacht..., s. 3.

16 Takiego terminu używa E. Gerke (Vertretungsmacht..., passim).

17 Tamże, s. 6; K. Larenz, M. Wolf, Allgemeiner..., s. 894.

18 W. Flume, Allgemeiner..., s. 839.

19 Tamże, s. 787; E. Gerke, Vertretungsmacht..., s. 3.

20 K. Larenz, M. Wolf, Allgemeiner..., s. 895-897; C. Schubert, w: Münchener Kommentar..., t. 1, \$164, Nb. 213-232.

21 A. Hueck, Das Recht der offenen Handelsgesellschaft. Systematisch dargestellt, wyd. 3, Berlin 1964, s. 82; P. Rawert, w: Münchener Kommentar zum Handelsgesetzbuch, t. 2, red. K. Schmidt, wyd. 4, München 2016, \$ 114, Nb. 6; I. Drescher, w: Handelsgesetzbuch, t. 1, red. D. Joost, L. Strohn, wyd. 4, München 2020, \$ 114, Nb. 4; J. Lieder, w: Kommentar zum Handelsgesetzbuch (HGB), red. H. Oetker, wyd. 7, München 2021, \$114, Nb. 4; H. Westermann, Personengesellschaftsrecht, Köln 1972, s. 115 (zob. jednak wypowiedź przywołaną dalej w przyp. 24); K. Schmidt, Gesellschaftsrecht, wyd. 2, KölnBerlin-Bonn-München 1991, s. 1145; M. Mack, Der Gleichlauf von Geschäftsführungsbefugnis und 
$\mathrm{w}$ interesie spółki ${ }^{22}$. Pojęcie prowadzenia spraw obejmuje nie tylko dokonywanie czynności prawnych, ale również wykonywanie czynności o charakterze faktycznym, takich jak kierowanie produkcją, organizowanie zbytu, prowadzenie ksiąg, prowadzenie korespondencji, sporządzenie bilansów ${ }^{23}$. Przy czym uznaje się, że prowadzenie spraw obejmuje również czynności prawne wywołujące skutki wobec osób trzecich. Przyjmuje się bowiem, że w pojęciu prowadzenia spraw zawiera się również dokonywanie czynności stanowiących reprezentowanie spółki wobec osób trzecich $^{24}$. Reprezentowanie stanowi wycinek prowadzenia spraw ${ }^{25}$.

Rozróżnienie na prowadzenie spraw i reprezentowanie tym samym nie oznacza, że ogół czynności podejmowanych na rzecz spółki należy podzielić na dwie grupy w ten sposób, że jedne należą do prowadzenia spraw, inne zaś do reprezentacji. Jedna i ta sama czynność może jednocześnie stanowić czynność prowadzenia spraw i reprezentacji. Ustawowe rozróżnienie na prowadzenie spraw i reprezentację ma na uwadze to, z jakiego punktu widzenia oceniamy daną czynność prawną. Z perspektywy stosunku wewnętrznego stanowi ona element prowadzenia spraw, z punktu widzenia stosunku zewnętrznego - przejaw reprezentacji ${ }^{26}$.

Przyjmuje się bowiem, że przepisy dotyczące prowadzenia spraw oraz przepisy dotyczące reprezentacji dotyczą różnych aspektów tych samych czynności. Regulacje dotyczące prowadzenia spraw dotyczą kwestii wewnętrznej odpowiedzialności związanej z dokonywanymi przez wspólnika czynnościami prawnymi, natomiast przepisy dotyczące reprezentacji - skuteczności tych czynności na zewnątrz. Umocowanie do reprezentowania (niem. Vertretungsmacht), regulowane przez przepisy dotyczące stosunku wspólników do osób trzecich, decyduje o tym, czy czynność prawna dokonana przez wspólnika wiąże spółkę wobec osoby trzeciej.

Vertretungsmacht, Frankfurt am Main-Berlin-Bern-New York-Paris-Wien 1998, s. 141; U. Schmidt-Tiedemann, Geschäftsführung und Vertretung im Gesellschaftsrecht Deutschlands, Frankreichs und Englands. Eine rechtsvergleichende Untersuchung zur Feststellung gemeineuropäischer Prinzipien des Gesellschaftsrechts, Frankfurt am Main 2004, s. 46.

22 C. Schäfer, w: Das Recht der $O H G \ldots, \$ 114, \mathrm{Nb} .11$. Z pojęcia prowadzenia spraw spółki wyłącza się tzw. czynności podstawowe (niem. Grundlagengeschäfte), zob. np. P. Rawert, w: Münchener Kommentar zum Handelsgesetzbuch, t. 2, \$114, Nb. 9-14.

23 A. Hueck, Das Recht der offenen Handelsgesellschaft..., s. 82 i 83.

24 C. Schäfer, w: Das Recht der OHG..., \$114, Nb. 11 i 14; P. Rawert, w: Münchener Kommentar zum Handelsgesetzbuch, t. 2, \$114, Nb. 15. Zob. jednak H. Westermann, Personengesellschaftsrecht, s. 103, gdzie autor, $\mathrm{z}$ wadliwym powołaniem się na poglądy A. Huecka, twierdzi, że prowadzenie spraw nie obejmuje składania i odbierania oświadczeń woli w imieniu spółki, co zresztą pozostaje w sprzeczności z innym twierdzeniem autora (s. 115), że czynność prawna może jednocześnie stanowić element prowadzenia spraw i reprezentacji.

25 M. Mack, Der Gleichlauf..., s. 143.

26 A. Hueck, Das Recht der offenen Handelsgesellschaft..., s. 83 i 84; U. Schmidt-Tiedemann, Geschäftsführung..., s. 48. 
Natomiast ocena kwestii, czy w stosunku wewnętrznym wspólnik mógł, bez naruszenia swoich obowiązków wobec pozostałych wspólników, dokonać danej czynności, następuje na podstawie przepisów o prowadzeniu spraw, a rozstrzyga o tym zakres przysługującego wspólnikowi uprawnienia do prowadzenia spraw (niem. Geschäftsführungsbefügnis) ${ }^{27}$. Innymi słowy, umocowanie do reprezentowania to rechtliches Können, zaś uprawnienie do prowadzenia spraw - rechtliches Dürfen ${ }^{28}$.

$\mathrm{Z}$ powyższych rozważań wynika, że relacja między umocowaniem do reprezentowania a uprawnieniem i obowiązkiem prowadzenia spraw jest $\mathrm{w}$ literaturze niemieckiej ujmowana dokładnie tak samo jak relacja między pełnomocnictwem a stosunkiem wewnętrznym (podstawowym). Stosunek wewnętrzny, regulujący zasady korzystania przez wspólnika $\mathrm{z}$ umocowania do reprezentowania, kształtują przepisy oraz postanowienia umowy spółki dotyczące prowadzenia spraw. Z nich wynika, czy wspólnik posiada - patrząc z perspektywy stosunku wewnętrznego prawo reprezentowania spółki. Przy ocenie skuteczności wobec osób trzecich czynności dokonywanych przez wspólnika w imieniu spółki znaczenie mają jednak przepisy o reprezentacji i regulowane tam pojęcie umocowania do reprezentowania. Jeżeli wspólnik umocowany do reprezentowania dokona czynności prawnej, nie posiadając - w ramach stosunku wewnętrznego - prawa do reprezentowania (jako elementu prawa prowadzenia spraw), czynność jest skuteczna wobec spółki ${ }^{29}$. Wyjątek stanowią przypadki nadużycia umocowania ${ }^{30}$.

\section{Prowadzanie spraw a reprezentowanie spółki - poglądy polskiej doktryny w świetle nauki o przedstawicielstwie}

Przedstawione wyżej uwagi, jak również okoliczność, że rozróżnienie na umocowanie oraz stosunek wewnętrzny przyjmowane jest również w polskiej nauce o przedstawicielstwie ${ }^{31}$, uzasadniają tezę, że przy analizie przepisów regulujących działanie wspólników w imieniu spółki jawnej użyteczna jest aparatura poję-

27 A. Hueck, Das Recht der offenen Handelsgesellschaft..., s. 84; P. Rawert, w: Münchener Kommentar zum Handelsgesetzbuch, t. 2, \$114, Nb. 15.

28 C. Schäfer, w: Das Recht der OHG..., \$ 114, Nb. 11; I. Drescher, w: Handelsgesetzbuch, t. 1, § 14, Nb. 5.

29 M. Habersack, w: Das Recht der OHG ..., \$126, Nb. 3.

30 Szerzej na temat przypadków nadużycia umocowania przez wspólnika jawnego zob. M. Habersack, w: Das Recht der OHG..., \$ 126, Nb. 23-27; K. Schmidt, w: Münchener Kommentar zum Handelsgesetzbuch, t. 2, \$126, Nb. 20-23.

31 B. Gawlik, w: System Prawa Cywilnego, t. 1. Część ogólna, red. S. Grzybowski, wyd. 2, WrocławWarszawa-Kraków-Gdańsk 1985, s. 734, 735, 754-757; M. Pazdan, w: System Prawa Prywatnego, 
ciowa wypracowana w nauce o przedstawicielstwie. Chodzi o trzy pojęcia. Po pierwsze, pojęcie „umocowania do reprezentowania”, będące elementem stosunku zewnętrznego, rozstrzygające o ważności czynności dokonywanych przez wspólników w imieniu spółki. Po drugie, pojęcie „prawa do reprezentowania”, które decyduje o tym, czy z perspektywy stosunku wewnętrznego wspólnik może dokonać aktu reprezentacji. Przez niektórych autorów jest ono określane mianem „upoważnienia” 32 - taki też termin będzie używany dalej na oznaczenie „prawa do reprezentowania”. Po trzecie, pojęcie „obowiązku reprezentowania”. To z kolei pojęcie rozstrzyga kwestię, czy z perspektywy stosunku wewnętrznego na wspólniku spoczywa obowiązek dokonywania czynności w imieniu spółki. Do oceny pozostaje zagadnienie, w jaki sposób oraz w których przepisach K.s.h. ustawodawca uregulował wskazane wyżej elementy współkształtujące zasady działania wspólników w imieniu spółki.

Jedną rzecz można uznać za bezdyskusyjną. Umocowanie do reprezentowania spółki wynika z przepisu art. $29 \$ 1$ K.s.h., zgodnie z którym każdy wspólnik „ma prawo reprezentować spółkę”. Mimo że art. $29 \$ 1$ K.s.h. nie używa terminu „umocowanie”, a jedynie „prawo” do reprezentowania, w literaturze nie budzi wątpliwości teza, że przepis ten rozstrzyga o skuteczności wobec osób trzecich czynności dokonywanych przez wspólników w imieniu spółki, zaś „prawo” do reprezentowania bywa traktowane jako synonim „umocowania” do reprezentowania ${ }^{33}$. Przedmiotem jego regulacji jest zatem - co najmniej - umocowanie do reprezentowania.

Miejsce i sposób regulacji stosunku wewnętrznego w literaturze nie przedstawia się już tak jasno. Wynika to przede wszystkim $\mathrm{z}$ różnic $\mathrm{w}$ ujmowaniu relacji między prowadzeniem spraw a reprezentacją i skoncentrowaniu zainteresowań badawczych właśnie na tym zagadnieniu. Widoczne są w tym zakresie dwa kierunki interpretacyjne.

t. 2. Prawo cywilne - część ogólna, red. Z. Radwański, A. Olejniczak, wyd. 3, Warszawa 2019, s. 644646; Z. Radwański, A. Olejniczak, Prawo cywilne - część ogólna, wyd. 15, Warszawa 2019, s. 352 i 353.

32 E. Płonka, Mechanizm łączenia skutków działań prawnych z osobami prawnymi na przykładzie spółek kapitałowych, Wrocław 1994, s. 51-54; J. Grykiel, Powstanie prokury, Warszawa 2008, s. 98.

33 G. Nita-Jagielski, w: J. Bieniak i in., Kodeks spółek handlowych. Komentarz, wyd. 7, Warszawa 2020, art. 29, Nb. 5, 10 i 14; B. Borowy, w: Kodeks spótek handlowych. Komentarz, red. Z. Jara, wyd. 3, Warszawa 2020, art. 29, Nb. 4 i 7; J. Strzępka, E. Zielińska, w: Kodeks spótek handlowych. Komentarz, red. J. Strzępka, wyd. 7, Warszawa 2015, art. 29, Nb. 4 i 5; J.P. Naworski, w: Kodeks spótek handlowych. Komentarz, t. 1, red. T. Siemiątkowski, R. Potrzeszcz, Warszawa 2011, art. 29, uw. 8; S. Sołtysiński, w: S. Sołtysiński i in., Kodeks spółek handlowych, t. 1. Przepisy ogólne. Spółki osobowe. Komentarz do artykułów 1-150, wyd. 3, Warszawa 2012, art. 29, Nb. 2; K. Kopaczyńska-Pieczniak, w: Kodeks spółek handlowych, t. 1, red. A. Kidyba, Warszawa 2017, art. 29, uw. 12 i 25; D. Bucior, w: Meritum. Prawo spółek, t. 1, red. A. Kidyba, wyd. 6, Warszawa 2020, Nb. 469. 
Zwolennicy pierwszego ujęcia, częściowo w nawiązaniu do doktryny niemieckiej i szwajcarskiej, twierdzą, że prowadzenie spraw obejmuje dokonywanie wszelkich czynności faktycznych i prawnych służących realizacji celu spółki, w tym dokonywanie czynności prawnych z osobami trzecimi. Reprezentacja stanowi zatem element prowadzenia spraw, zaś obydwa pojęcia mają na uwadze różny aspekt tych samych czynności ${ }^{34}$. Wskazuje się, że przepisy o reprezentacji decydują o przesłankach związania spółki czynnościami dokonywanymi przez wspólników, natomiast przepisy o prowadzeniu spraw służą ocenie prawidłowości dokonywanych czynności z perspektywy stosunków wewnętrznych i mogą mieć znaczenie zwłaszcza z perspektywy odpowiedzialności wspólnika wobec spółki ${ }^{35}$.

Takie spojrzenie na relację między prowadzeniem spraw a reprezentacją oraz relację między przepisami regulującymi obydwa aspekty działań wspólników musi prowadzić do wniosku, że upoważnienie do reprezentowania - jako element stosunku wewnętrznego - jest regulowane przez przepisy o prowadzeniu spraw. Stanowi tym samym element prawa prowadzenia spraw spółki. Wspólnik tylko wtedy może dokonać czynności prawnej w imieniu spółki, jeżeli posiada prawo prowadzenia spraw w odniesieniu do danej czynności.

Zgodnie $\mathrm{z}$ alternatywnym poglądem reprezentowanie nie stanowi elementu prowadzenia spraw. Są to dwie rozłączne, choć powiązane ze sobą grupy czynności. Czynności z zakresu reprezentacji opisywane są jako składanie oświadczeń woli $\mathrm{w}$ imieniu spółki ${ }^{36}$ lub też szerzej jako występowanie we wszystkich stosunkach prawnych z zakresu prawa cywilnego, prawa administracyjnego, prawa pracy lub innych gałęzi prawa, co obejmuje nie tylko dokonywanie czynności cywilnoprawnych, ale również ujawnianie stanowiska spółki na zewnątrz, składanie oświadczeń

34 S. Sołtysiński, w: S. Sołtysiński i in., Kodeks..., t. 1, art. 38, Nb. 5, art. 39, Nb. 1; S. Sołtysiński, P. Moskwa, w: System Prawa Prywatnego, t. 16. Prawo spółek osobowych, red. A. Szajkowski, wyd. 2, Warszawa 2016, s. 1073; W. Pyzioł, w: Kodeks spółek handlowych. Komentarz, red. W. Pyzioł, Warszawa 2008, art. 29, uw. 1, art. 39 uw. 2; A. Herbet, Spółka komandytowa według Kodeksu spółek handlowych. Komentarz, Lublin 2004, s. 152, 153 i 184; G. Gorczyński, Spótka jawna jako podmiot prawa, Warszawa 2009, s. 187 i 188; K. Osajda, Spółki osobowe w najnowszym orzecznictwie Sądu Najwyższego - odpowiedzialność spótki i wspólników, Glosa 2007, nr 2, s. 7 i 8; D. Bucior, w: Meritum..., Nb. 400. Podobnie wyrok SN z dnia 11 stycznia 2006 r., III CK 328/05, LEX nr 448044. W wyroku SA w Krakowie z dnia 10 maja 2018 r., I AGa 110/18, LEX nr 2582652, za prowadzenie spraw spółki uznano „wiązkę, wzajemnie powiązanych ze sobą funkcjonalnie, czynności natury faktycznej, w tym organizacyjno-technicznej oraz prawnej, których skutki zmierzają do realizacji celu, w jakim spółka została powołana".

35 S. Sołtysiński, w: S. Sołtysiński i in., Kodeks..., t. 1, art. 38, Nb. 5; art. 39, Nb. 2; A. Herbet, Spółka komandytowa..., s. 153, 184 i 185; D. Bucior, w: Meritum..., Nb. 401, 470.

36 J. Strzępka, E. Zielińska, w: Kodeks..., red. J. Strzępka, art. 29, Nb. 1; M. Rodzynkiewicz, Kodeks spółek handlowych. Komentarz, wyd. 7, Warszawa 2018, art. 29, uw. 1. 
i wyjaśnień przed organami administracyjnymi i orzekającymi ${ }^{37}$. Z kolei prowadzenie spraw obejmować ma przede wszystkim czynności faktyczne opisywane np. jako kierowanie, zarządzanie, organizowanie czy podejmowanie decyzji ${ }^{38}$, ewentualnie także czynności prawne, ale tylko takie, które nie wywołują skutków prawnych wobec osób trzecich (np. uchwały) ${ }^{39}$.

Odnosząc przedstawione ujęcie do procesu dokonywania przez spółkę czynności prawnych, można je uprościć do następującego schematu: a) decyzja o dokonaniu czynności, podjęta przez wspólnika samodzielnie (art. $39 \$ 1$ K.s.h.) lub przez wspólników w formie uchwały (art. $39 \$ 2$ K.s.h.), stanowi element prowadzenia spraw; b) wykonanie tej decyzji w drodze złożenia w imieniu spółki oświadczenia woli stanowi przejaw reprezentowania. Przy czym relacja między obydwoma elementami jest ujmowana w ten sposób, że brak lub wadliwość procesu decyzyjnego nie wpływa na ważność czynności prawnej dokonanej w ramach reprezentacji spółki ${ }^{40}$.

Rozbicie procesu dokonywania czynności prawnych na dwa etapy: decyzyjny i wykonawczy oraz poddanie tych etapów odmiennemu reżimowi prawnemu (etap decyzyjny - przepisy o prowadzeniu spraw; etap wykonawczy - przepisy o reprezentacji) nie prowadzi do jednoznacznej odpowiedzi na pytanie o miejsce regulacji

37 A. Kidyba, Handlowe spótki osobowe, wyd. 4, Warszawa 2013, s. 171; K. Kopaczyńska-Pieczniak, Pozycja prawna wspólnika spółki jawnej, Warszawa 2013, s. 122 i 123; J.P. Naworski, w: Kodeks..., t. 1, red. T. Siemiątkowski, R. Potrzeszcz, art. 29, uw. 1.

38 Stosowana terminologia oraz sposób opisu pojęcia prowadzanie spraw są różne, zob. np. A. Kidyba, Handlowe spótki..., s. 164; K. Kopaczyńska-Pieczniak, Pozycja prawna..., s. 164-167 (i zebrane tam poglądy doktryny); A.J. Witosz, Prowadzenie spraw i reprezentacja spółek osobowych, Warszawa 2013, s. 37-51 (i zebrane tam poglądy doktryny); J. Kruczalak-Jankowska, K. Trzciński, Kilka uwag na temat zakresu pojęciowego prowadzenia spraw i reprezentacji w spótkach osobowych w kodeksie spółek handlowych, w: Kodeks spółek handlowych po pięciu latach, Wrocław 2006, s. 362 i 363; B. Borowy, w: Kodeks..., red. Z. Jara, art. 29, Nb. 2; art. 39, Nb. 1; J. Strzępka, E. Zielińska, w: Kodeks..., red. J. Strzępka, art. 29, Nb. 1, art. 38, Nb. 1; R. Potrzeszcz, T. Siemiątkowski, w: Kodeks..., t. 1, red. T. Siemiątkowski, R. Potrzeszcz, art. 39, uw. 1; M. Litwińska, w: System Prawa Handlowego, t. 2A. Prawo spółek handlowych, red. A. Szumański, S. Włodyka, wyd. 3, Warszawa 2019, s. 421. Podobnie: wyrok SN z dnia 5 września 2012 r., IV CSK 137/12, LEX nr 1229817; wyrok SA w Lublinie z dnia 15 listopada 2012 r., I ACa 522/12, LEX nr 1267376.

39 K. Kopaczyńska-Pieczniak, Pozycja prawna..., s. 166.

40 G. Nita-Jagielski, w: J. Bieniak i in., Kodeks..., art. 39, Nb. 9; B. Borowy, w: Kodeks..., red. Z. Jara, art. 39, Nb. 24; R. Potrzeszcz, T. Siemiątkowski, w: Kodeks..., t. 1, red. T. Siemiątkowski, R. Potrzeszcz, art. 39, uw. 7; K. Kopaczyńska-Pieczniak, Pozycja prawna..., s. 191; K. Kopaczyńska-Pieczniak, (Nie) zależność reprezentacji od prowadzenia spraw w handlowych spółkach osobowych, Przegląd Prawa Handlowego 2019, nr 9, s. 12 i 13; A.J. Witosz, Prowadzenie spraw..., s. 256 i 257. Odmiennie A. Kidyba, Relacje między prowadzeniem spraw a reprezentacja w spółce jawnej i skutki $z$ nich wynikające, w: Rozprawy z prawa prywatnego. Ksiega jubileuszowa dedykowana Profesorowi Wojciechowi Popiotkowi, red. M. Jagielska, E. Rott-Pietrzyk, M. Szpunar, Warszawa 2017, s. 417 i 418. 
upoważnienia do reprezentowania jako elementu stosunku wewnętrznego. Pierwsza myśl jest taka: skoro reprezentowanie jako etap wykonawczy podlega odrębnemu reżimowi prawnemu, to upoważnienie do reprezentowania wynika wyłącznie Z art. $29 \$ 1$ K.s.h. Przy takim ujęciu przepis ten musiałby być postrzegany jako źródło zarówno umocowania do reprezentowania, jak i upoważnienia do reprezentowania. Przepisy o prowadzeniu spraw byłyby irrelewantne dla oceny upoważnienia do reprezentowania. Ten wariant interpretacyjny można jednak z miejsca odrzucić - żaden $\mathrm{z}$ autorów zresztą takiego wariantu nie broni. Prowadzi on bowiem do wniosku, że przepisy o prowadzeniu spraw, w szczególności przepisy dotyczące prawa sprzeciwu (art. $39 \$ 3$ K.s.h.) czy wymogu uchwał w sprawach nadzwyczajnych (art. 43 K.s.h.), pozbawione byłyby jakiegokolwiek znaczenia przy dokonywaniu czynności prawnych w imieniu spółki, skoro wspólnik umocowany do reprezentowania - z perspektywy stosunku wewnętrznego - byłby zawsze upoważniony do reprezentowania, niezależnie od tego, czy w ramach prowadzenia spraw została podjęta prawidłowa decyzja.

Być może tezę, że prowadzenie spraw i reprezentacja to dwie odrębne grupy czynności poddane osobnemu reżimowi, należy wyjaśniać w ten sposób, że art. 29 $\$ 1$ K.s.h. reguluje upoważnienie do reprezentowania, ale nie w sposób wyłączny. Elementem regulacji dotyczącej upoważnienia do reprezentowania byłyby również przepisy o prowadzeniu spraw. W pierwszej kolejności konieczne byłoby ustalenie - na podstawie przepisów o prowadzeniu spraw - czy w ramach prowadzenia spraw została podjęta decyzja o dokonaniu danej czynności. Jeżeli taka decyzja została podjęta, w kolejnym kroku należałoby zbadać, czy wspólnik, który w imieniu spółki dokonał tej czynności, posiadał upoważnienie do jej dokonania, czyli prawo wykonania decyzji podjętej $\mathrm{w}$ ramach prowadzenia spraw. Ta kwestia podlegałaby ocenie w świetle art. $29 \$ 1$ K.s.h. jako przepisu tworzącego odrębny reżim prawny reprezentacji. Oznaczałoby to z kolei, że przepis art. $29 \$ 1$ K.s.h. odgrywa rolę na dwóch płaszczyznach. Z jednej strony stanowi źródło skutecznego w stosunku zewnętrznym umocowania do reprezentowania. $Z$ drugiej zaś, w przypadku podjęcia przez wspólnika lub wspólników w ramach prowadzenia spraw decyzji co do dokonania czynności, przepis ten daje wspólnikowi skuteczne wewnętrznie upoważnienie do reprezentowania, czyli wykonania tej decyzji.

Niewykluczone, że właśnie w ten sposób postrzegany jest sposób regulacji upoważnienia do reprezentowania przez zwolenników wąskiego rozumienia prowadzenia spraw, choć dokonanie jednoznacznych ustaleń co do poglądów poszczególnych autorów nie jest łatwe $\mathrm{z}$ uwagi na przyjętą przez nich perspektywę badawczą (skoncentrowanie na relacji między prowadzeniem spraw a reprezentacją, a nie na relacji między umocowaniem do reprezentowania a stosunkiem wewnętrznym). 
Z wypowiedzi wskazujących na to, że z przepisu art. $29 \$ 1$ K.s.h. „wynika prawo wspólnika do reprezentowania, a nie jego obowiązek" ${ }^{31}$, czy też stawiających na tej samej płaszczyźnie „prawo reprezentowania” z art. $29 \$ 1$ K.s.h. z prawem prowadzenia spraw z art. $39 \$ 1$ K.s.h.42, można chyba wyciągnąć wniosek, że „prawo reprezentowania", o którym stanowi art. $29 \$ 1$ K.s.h., jest traktowane nie tylko jako element stosunku zewnętrznego, lecz również stosunku wewnętrznego. Być może w ten sam sposób należy odczytywać twierdzenia, że wynikające z art. $29 \$ 1$ K.s.h. "prawo reprezentowania" może być ograniczone ze skutkiem wewnętrznym ${ }^{43}$ - co może sugerować, że art. $29 \$ 1$ K.s.h. wywołuje skutki w stosunku wewnętrznym, które to skutki mogą zostać ograniczone w umowie spółki.

$\mathrm{W}$ podsumowaniu dotychczasowych uwag można stwierdzić, że w zależności od sposobu (szerokiego lub wąskiego) rozumienia prowadzenia spraw inaczej wypada ocena podstawy prawnej upoważnienia do reprezentowania - jako elementu stosunku wewnętrznego. W przypadku szerokiego rozumienia prowadzenia spraw podstawę taką tworzą przepisy dotyczące prowadzenia spraw, w szczególności art. $39 \$ 1$ i 2 K.s.h. Jeżeli natomiast prowadzenie spraw rozumiemy wąsko, podstawą upoważnienia do reprezentowania jest - obok przepisów regulujących prowadzenie spraw - jak się wydaje także przepis art. $29 \$ 1$ K.s.h.

Konsekwencje praktyczne obu ujęć można zobrazować na przykładach.

\section{Przykład 1}

W spółce jawnej obowiązują kodeksowe zasady prowadzenia spraw, tzn. każdy wspólnik ma prawo prowadzenia spraw, przy czym czynność nadzwyczajna wymaga uchwały wszystkich wspólników (art. 39 \$ 1 i 2, art. 43 K.s.h.). Umowa spółki nie zawiera postanowień dotyczących reprezentacji. Wspólnicy podjęli uchwałę o dokonaniu czynności nadzwyczajnej - czyli została podjęta decyzja o dokonaniu czynności. Pytanie: który ze wspólników ma upoważnienie do dokonania tej czynności poprzez złożenie oświadczenia woli w imieniu spółki?

41 A. Kidyba, Komentarz aktualizowany do art. 1-300 Kodeksu spótek handlowych, 2021 [wyd. el. LEX], art. 29, uw. 2. Podobnie B. Borowy, w: Kodeks..., red. Z. Jara, art. 29, Nb. 3; J.P. Naworski, w: Kodeks..., t. 1, red. T. Siemiątkowski, R. Potrzeszcz, art. 29, uw. 2; art. 30, uw. 36; T. Sidor, Reprezentacja handlowych spótek osobowych, Przegląd Prawa Handlowego 2006, nr 1, s. 18.

42 Np. B. Borowy, w: Kodeks..., red. Z. Jara, art. 29, Nb. 3: „Na podstawie art. 29 KSH stwierdzić należy, że reprezentacja jest prawem wspólnika [...], natomiast prowadzenie spraw spółki, co do zasady, jest zarówno uprawnieniem wspólnika, jak również jego obowiązkiem (art. $39 \mathrm{KSH}$ )”. Podobnie T. Sidor, Reprezentacja..., s. 18.

43 B. Borowy, w: Kodeks..., red. Z. Jara, art. 29, Nb. 22; J. Strzępka, E. Zielińska, w: Kodeks..., red. J. Strzępka, art. 29, Nb. 5; M. Rodzynkiewicz, Kodeks..., art. 29, uw. 4; A. Kidyba, Komentarz aktualizowany ..., art. 29, uw. 3; K. Kopaczyńska-Pieczniak, Pozycja prawna..., s. 136. 
Odpowiedź na powyższe pytanie będzie taka sama, niezależnie od tego, czy prowadzenie spraw ujmujemy szeroko czy wąsko - uprawnionym do dokonania czynności prawnej będzie każdy wspólnik. Różna będzie jedynie podstawa prawna upoważnienia do reprezentowania: albo art. $39 \$ 1$ i 2 K.s.h. (ujęcie szerokie) albo art. $29 \$ 1$ K.s.h. w powiązaniu z art. $39 \$ 2$ K.s.h. (ujęcie wąskie). Okazuje się zatem, że w sytuacji, gdy obowiązują reguły kodeksowe w zakresie prowadzenia spraw i każdemu wspólnikowi przysługuje umocowanie do reprezentowania, z punktu widzenia oceny upoważnienia wspólnika do reprezentowania nie ma znaczenia, czy reprezentowanie będziemy ujmować jako element prowadzenia spraw, czy też nie. Praktyczne rezultaty obu stanowisk są identyczne.

Różnice mogą się pojawić w sytuacji, gdy umowa spółki modyfikuje kodeksowe zasady prowadzenia spraw.

\section{Przykład 2}

Spółka jawna składa się z trzech wspólników: A, B i C. W umowie spółki postanowiono, że prowadzenie spraw w zakresie nabywania środków transportowych należy do wyłącznej kompetencji wspólnika A. Jednocześnie postanowiono, że uchwały wspólników wymagają wszelkie czynności o wartości przekraczającej 100 tys. zł, w tym te dotyczące nabywania środków transportowych. Umowa spółki nie zawiera postanowień dotyczących reprezentacji, co oznacza, że każde$\mathrm{mu}$ wspólnikowi przysługuje umocowanie do reprezentowania zgodnie z art. 29 $\$ 1$ K.s.h. Na wniosek wspólnika A wspólnicy podjęli uchwałę o zakupie pojazdu za cenę nieprzekraczającą 150 tys. zł. Ponownie pytanie: który wspólnik ma uprawnienie do zawarcia tej umowy?

Jeżeli prowadzenie spraw rozumiemy szeroko, to kwestię upoważnienia do zawarcia umowy sprzedaży w wykonaniu podjętej uchwały należy oceniać w świetle przepisów i postanowień umowy spółki o prowadzeniu spraw. W takim przypadku wyłącznie wspólnik A ma skuteczne wewnętrznie upoważnienie do zawarcia umowy sprzedaży w wykonaniu tej uchwały, gdyż tylko on posiada prawo prowadzenia spraw w zakresie nabywania środków transportowych. Pozostali wspólnicy: B i C, mimo że posiadają umocowanie do reprezentowania, to z perspektywy stosunku wewnętrznego nie są upoważnieni do zawarcia tej umowy.

Jeżeli natomiast prowadzenie spraw rozumiemy wąsko, to postanowienie umowy spółki przyznające wspólnikowi A wyłączne prawo prowadzenia spraw spółki w zakresie nabywania środków transportowych należy interpretować w ten sposób, że dotyczy ono tylko etapu decyzyjnego - nie rozciąga się na etap wykonawczy. W konsekwencji uznamy, że w omawianym przykładzie upoważnienie do reprezentowania przysługuje każdemu wspólnikowi - gdyż została podjęta prawidłowa 
uchwała, zaś ich upoważnienie do reprezentowania wynikające z art. $29 \$ 1$ K.s.h. nie zostało w umowie spółki w tym zakresie ograniczone.

Różnice między obydwoma ujęciami ujawniają się również w odniesieniu do kwestii, czy wspólnik umocowany do reprezentowania ma obowiązek reprezentowania.

Konsekwencją stanowiska traktującego reprezentowanie jako element prowadzenia spraw musi być teza, że przejawem obowiązku prowadzenia spraw jest obowiązek reprezentowania. Odpowiedź na pytanie, czy na wspólniku umocowanym do reprezentowania ciąży obowiązek dokonywania aktów reprezentacji, winna być zatem rezultatem oceny, czy i w jakim zakresie dany wspólnik jest zobowiązany do prowadzenia spraw. Ta konsekwencja jest dostrzegana przez niektórych zwolenników tego ujęcia ${ }^{44}$. Formułowany jest jednak również pogląd, który nie wyprowadza obowiązku reprezentowania bezpośrednio z obowiązku prowadzenia spraw, lecz wskazuje, że istnienie tego obowiązku należy oceniać na podstawie treści umowy spółki, przy czym co do zasady „milczenie umowy przemawia za istnieniem obowiązku reprezentacji spółki osobowej, której przedsiębiorstwo wymaga $\mathrm{z}$ reguły prowadzenia i reprezentowania przez wszystkich wspólników (art. 56 i 65 $\S 1$ i 2 KC)" 45 .

Z kolei pogląd, zgodnie z którym reprezentacja i prowadzenie spraw stanowią zbiory rozłączne, prowadzi do oczywistych problemów z ustaleniem, czy na wspólniku umocowanym do reprezentowania ciąży obowiązek reprezentowania. Brak jest wtedy możliwości uznania, że art. $39 \$ 1$ K.s.h., dotyczący obowiązku prowadzenia spraw, obejmuje również obowiązek reprezentowania. Niektórzy autorzy negują zatem istnienie takiego obowiązku ${ }^{46}$, ewentualnie wyprowadzają go z ogólnego obowiązku dążenia do osiągnięcia wspólnego celu, stanowiącego element konstytutywny umowy spółki (art. 3 K.s.h.) ${ }^{47}$.

\section{Stanowisko własne}

W mojej ocenie uzasadniona jest interpretacja, zgodnie z którą prowadzenie spraw obejmuje również reprezentowanie.

\footnotetext{
44 A. Herbet, Spółka komandytowa..., s. 155; D. Bucior, w: Meritum..., Nb. 401.

45 S. Sołtysiński, w: S. Sołtysiński i in., Kodeks..., t. 1, art. 29, Nb. 3.

46 A. Kidyba, Handlowe spółki..., s. 156; B. Borowy, w: Kodeks..., red. Z. Jara, art. 29, Nb. 3; J.P. Naworski, w: Kodeks..., t. 1, red. T. Siemiątkowski, R. Potrzeszcz, art. 29, uw. 2.

47 K. Kopaczyńska-Pieczniak, Pozycja prawna..., s. 123 i 124; A.J. Witosz, Prowadzenie spraw..., s. 124.
} 
Po pierwsze, taka wykładnia znajduje wsparcie w systematyce K.s.h. Przepisy o prowadzeniu spraw pomieszczone są wśród przepisów dotyczących „stosunków wewnętrznych spółki” (tytuł II, dział I, rozdział 3 K.s.h.), zaś przepisy o reprezentacji - w ramach regulacji mającej za przedmiot „stosunek do osób trzecich” (tytuł II, dział I, rozdział 2 K.s.h.). Szerokie rozumienie prowadzenia spraw skutkuje tym, że całość stosunku wewnętrznego związanego z realizacją umocowania do reprezentowania (tzn. zarówno etap decyzyjny, jak i wykonawczy) oceniana jest na podstawie przepisów dotyczących stosunków wewnętrznych. Trudno wyjaśnić, dlaczego ustawodawca miałby część stosunku wewnętrznego (tzn. w zakresie etapu wykonawczego) regulować przez przepisy dotyczące stosunku do osób trzecich.

Po drugie, za szerokim rozumieniem prowadzenia spraw przemawia treść art. $39 \$ 2$ K.s.h., zgodnie z którym każdy wspólnik może bez uprzedniej uchwały wspólników prowadzić sprawy nieprzekraczające zakresu zwykłych czynności spółki. Przepis ten wskazuje, że przeprowadzenie danej sprawy - w zależności od jej charakteru - może wymagać lub może nie wymagać uchwały wspólników. Czytany a contrario wskazuje, że wspólnik może prowadzić sprawę dotyczącą czynności nadzwyczajnej dopiero po uzyskaniu uprzedniej uchwały wspólników (wskazanej w art. 43 K.s.h.). Przepis ten prowadzenie spraw traktuje zatem szeroko, tzn. obejmuje nim również - a może nawet: przede wszystkim - etap wykonawczy.

Po trzecie, nie budzi wątpliwości teza, że prowadzenie spraw obejmuje również czynności faktyczne, niezwiązane z dokonywaniem czynności prawnych. Szerokie rozumienie prowadzenia spraw pozwala na uniknięcie kłopotliwego pytania, dlaczego w odniesieniu do czynności faktycznych przepisy o prowadzeniu spraw obejmują zarówno etap decyzyjny, jak i etap wykonawczy, zaś w odniesieniu do aktów reprezentacji miałyby obejmować jedynie etap decyzyjny. Brak jest uzasadnienia dla takiego zróżnicowania. W szczególności takie uzasadnienie nie wynika z faktu, że ustawodawca zamieścił w K.s.h. odrębne przepisy dotyczące reprezentacji. To, że tak uczynił, wynika jedynie z potrzeby uregulowania stosunku zewnętrznego tzn. potrzebne są przepisy, które regulują zasady przypisywania spółce skutków działań wspólników. I to jest - moim zdaniem - wyłączny cel przepisów o reprezentacji: uregulowanie umocowania do reprezentowania, czyli zewnętrznego aspektu dokonywania przez wspólników czynności w imieniu spółki. Skoro taki jest cel tych przepisów, to nie ma powodów, aby z faktu ich istnienia wyciągać wniosek, że proces dokonywania czynności prawnych winien być - z perspektywy stosunku wewnętrznego - rozdzielony na dwa etapy (decyzyjny i wykonawczy), podlegające odrębnemu reżimowi. Proces ten powinien podlegać w całości regułom ustanowionym przez ustawodawcę dla stosunków wewnętrznych w spółce, czyli przepisom o prowadzeniu spraw. 
Po czwarte, traktowanie reprezentowania jako elementu prowadzenia spraw powoduje, że nie pojawia się problem, czy na wspólniku ciąży obowiązek reprezentowania oraz jaka jest jego podstawa prawna. Podstawą takiego obowiązku jest art. 39 $\$ 1$ K.s.h., zgodnie z którym wspólnik jest obowiązany prowadzić sprawy spółki.

Prowadzi to do następujących wniosków: a) prowadzenie spraw obejmuje również reprezentowanie; b) przepis art. $29 \$ 1$ K.s.h. reguluje tylko stosunek zewnętrzny, co oznacza, że „prawo reprezentowania”, o którym mowa w tym przepisie, oznacza wyłącznie „umocowanie do reprezentowania”, decydujące o skuteczności wobec spółki czynności zdziałanych przez wspólników w imieniu spółki; c) stosunek wewnętrzny dla umocowania do reprezentowania, zarówno w zakresie etapu decyzyjnego, jak i wykonawczego, regulowany jest przez przepisy o prowadzeniu spraw; d) przepisy o prowadzeniu spraw rozstrzygają: (i) czy wspólnik umocowany do reprezentowania może skorzystać z umocowania, czyli czy posiada prawo (upoważnienie) reprezentowania; (i) czy wspólnik umocowany do reprezentowania jest obowiązany dokonywać aktów reprezentacji.

\section{Bibliografia}

Borowy B., w: Kodeks spótek handlowych. Komentarz, red. Z. Jara, wyd. 3, Warszawa 2020. Bucior D., w: Meritum. Prawo spółek, t. 1, red. A. Kidyba, wyd. 6, Warszawa 2020.

Drescher I., w: Handelsgesetzbuch, t. 1, red. D. Joost, L. Strohn, wyd. 4, München 2020.

Flume W., Allgemeiner Teil des Bürgerlichen Rechts, t. 2, wyd. 2, Berlin-Heidelberg-New York 1975.

Gawlik B., w: System Prawa Cywilnego, t. 1. Część ogólna, red. S. Grzybowski, wyd. 2, Wrocław-Warszawa-Kraków-Gdańsk 1985.

Gerke E., Vertretungsmacht und Vertretungsberechtigung. Eine civilistische Untersuchung, KölnBerlin-Bonn-München 1981.

Gorczyński G., Spółka jawna jako podmiot prawa, Warszawa 2009.

Grykiel J., Powstanie prokury, Warszawa 2008.

Habersack M., w: M. Habersack, C. Schäfer, Das Recht der OHG. Kommentierung der \$\$ 105 bis 160 HGB, Berlin-New York 2010.

Herbet A., Spółka komandytowa według Kodeksu spółek handlowych. Komentarz, Lublin 2004.

Hueck A., Das Recht der offenen Handelsgesellschaft. Systematisch dargestellt, wyd. 3, Berlin 1964.

Kidyba A., Handlowe spółki osobowe, wyd. 4, Warszawa 2013.

Kidyba A., Komentarz aktualizowany do art. 1-300 Kodeksu spółek handlowych, 2021 [wyd. el. LEX].

Kidyba A., Relacje między prowadzeniem spraw a reprezentacja $w$ spółce jawnej i skutki $z$ nich wynikajace, w: Rozprawy z prawa prywatnego. Ksiega jubileuszowa dedykowana 
Profesorowi Wojciechowi Popiołkowi, red. M. Jagielska, E. Rott-Pietrzyk, M. Szpunar, Warszawa 2017.

Kopaczyńska-Pieczniak K., (Nie)zależność reprezentacji od prowadzenia spraw w handlowych spółkach osobowych, Przegląd Prawa Handlowego 2019, nr 9.

Kopaczyńska-Pieczniak K., Pozycja prawna wspólnika spótki jawnej, Warszawa 2013.

Kopaczyńska-Pieczniak K., w: Kodeks spółek handlowych, t. 1, red. A. Kidyba, Warszawa 2017.

Kruczalak-Jankowska J., Trzciński K., Kilka uwag na temat zakresu pojęciowego prowadzenia spraw i reprezentacji $w$ spótkach osobowych $w$ kodeksie spółek handlowych, w: Kodeks spółek handlowych po pięciu latach, Wrocław 2006.

Laband P., Die Stellvertretung bei dem Abschluß von Rechtsgeschäften nach dem allgem. Deutsch. Handelsgesetzbuch, Zeitschrift für das gesamte Handelsrecht (1866), t. 10.

Larenz K., Wolf M., Allgemeiner Teil des Bürgerlichen Rechts, wyd. 8, München 1997.

Lieder J., w: Kommentar zum Handelsgesetzbuch (HGB), red. H. Oetker, wyd. 7, München 2021.

Litwińska M., w: System Prawa Handlowego, t. 2A. Prawo spółek handlowych, red. A. Szumański, S. Włodyka, wyd. 3, Warszawa 2019.

Mack M., Der Gleichlauf von Geschäftsführungsbefugnis und Vertretungsmacht, Frankfurt am Main-Berlin-Bern-New York-Paris-Wien 1998.

Naworski J.P., w: Kodeks spółek handlowych. Komentarz, t. 1, red. T. Siemiątkowski, R. Potrzeszcz, Warszawa 2011.

Nita-Jagielski G., w: J. Bieniak i in., Kodeks spółek handlowych. Komentarz, wyd. 7, Warszawa 2020.

Osajda K., Spótki osobowe w najnowszym orzecznictwie Sądu Najwyższego - odpowiedzialność spótki i wspólników, Glosa 2007, nr 2.

Pazdan M., w: System prawa prywatnego, t. 2. Prawo cywilne - część ogólna, red. Z. Radwański, A. Olejniczak, wyd. 3, Warszawa 2019.

Płonka E., Mechanizm łączenia skutków działań prawnych z osobami prawnymi na przykładzie spółek kapitałowych, Wrocław 1994.

Potrzeszcz R., Siemiątkowski T., w: Kodeks spółek handlowych. Komentarz, t. 1, red. T. Siemiątkowski, R. Potrzeszcz, Warszawa 2011.

Pyzioł W., w: Kodeks spółek handlowych. Komentarz, red. W. Pyzioł, Warszawa 2008.

Radwański Z, Olejniczak A., Prawo cywilne - czesść ogólna, wyd. 15, Warszawa 2019.

Rawert P., w: Münchener Kommentar zum Handelsgesetzbuch, t. 2, red. K. Schmidt, wyd. 4, München 2016.

Rodzynkiewicz M., Kodeks spółek handlowych. Komentarz, wyd. 7, Warszawa 2018.

Schäfer C., w: M. Habersack, C. Schäfer, Das Recht der OHG. Kommentierung der \$\$ 105 bis 160 HGB, Berlin-New York 2010.

Schmidt K., Gesellschaftsrecht, wyd. 2, Köln-Berlin-Bonn-München 1991.

Schmidt K., w: Münchener Kommentar zum Handelsgesetzbuch, t. 2, red. K. Schmidt, wyd. 4, München 2016.

Schmidt-Tiedemann U., Geschäftsführung und Vertretung im Gesellschaftsrecht Deutschlands, Frankreichs und Englands. Eine rechtsvergleichende Untersuchung zur Feststellung gemeineuropäischer Prinzipien des Gesellschaftsrechts, Frankfurt am Main 2004. 
Schubert C., w: Münchener Kommentar zum Bürgerlichen Gesetzbuch, t. 1, red. C. Schubert, wyd. 8, München 2018.

Sidor T., Reprezentacja handlowych spółek osobowych, Przegląd Prawa Handlowego 2006, nr 1.

Sołtysiński S., w: S. Sołtysiński i in., Kodeks spółek handlowych. t. 1. Przepisy ogólne. Spółki osobowe. Komentarz do artykułów 1-150, wyd. 3, Warszawa 2012.

Sołtysiński S., Moskwa P., w: System prawa prywatnego, t. 16. Prawo spółek osobowych, red. A. Szajkowski, wyd. 2, Warszawa 2016.

Strzępka J., Zielińska E., w: Kodeks spółek handlowych. Komentarz, red. J. Strzępka, wyd. 7, Warszawa 2015.

Westermann H., Personengesellschaftsrecht, Köln 1972.

Witosz A.J., Prowadzenie spraw i reprezentacja spółek osobowych, Warszawa 2013. 